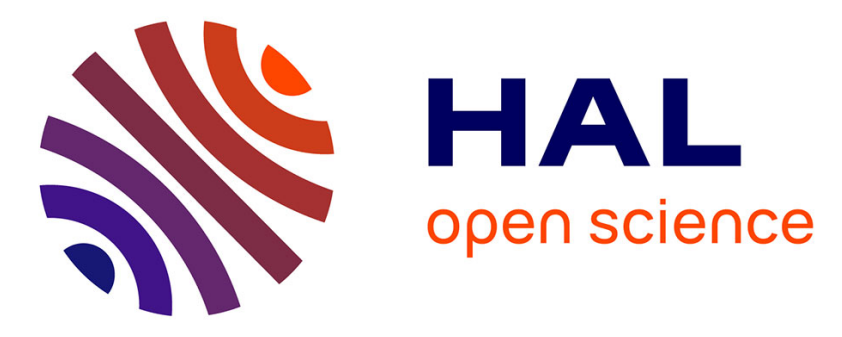

\title{
Characterization and application of a family B DNA polymerase from the hyperthermophilic and radioresistant euryarchaeon Thermococcus gammatolerans
}

Likui Zhang, Donghao Jiang, Haoqiang Shi, Mai Wu, Qi Gan, Zhihui Yang, Philippe M. Oger

\section{To cite this version:}

Likui Zhang, Donghao Jiang, Haoqiang Shi, Mai Wu, Qi Gan, et al.. Characterization and application of a family B DNA polymerase from the hyperthermophilic and radioresistant euryarchaeon Thermococcus gammatolerans. International Journal of Biological Macromolecules, 2020, 156, pp.217-224. 10.1016/j.ijbiomac.2020.03.204 . hal-02526997

\section{HAL Id: hal-02526997 https://hal.science/hal-02526997}

Submitted on 17 Jun 2020

HAL is a multi-disciplinary open access archive for the deposit and dissemination of scientific research documents, whether they are published or not. The documents may come from teaching and research institutions in France or abroad, or from public or private research centers.
L'archive ouverte pluridisciplinaire HAL, est destinée au dépôt et à la diffusion de documents scientifiques de niveau recherche, publiés ou non, émanant des établissements d'enseignement et de recherche français ou étrangers, des laboratoires publics ou privés. 


\title{
Characterization and application of a Family B DNA polymerase from the
} hyperthermophilic and radioresistant euryarchaeon Thermococcus

\author{
gammatolerans \\ Likui Zhang ${ }^{1,4 \#, ~ D o n g h a o ~ J i a n g ~}{ }^{1}$, Haoqiang Shi ${ }^{1}$, Mai Wu ${ }^{1}$, Qi Gan ${ }^{1}$, Zhihui Yang ${ }^{2 \#, ~}$ \\ and Philippe Oger ${ }^{3 \#}$ \\ ${ }^{1}$ Marine Science \& Technology Institute, College of Environmental Science and \\ Engineering, Yangzhou University, Jiangsu Province 225127, China \\ ${ }^{2}$ College of Plant Protection, Agricultural University of Hebei, Baoding City, Hebei \\ Province 071001, China \\ ${ }^{3}$ Univ Lyon, INSA de Lyon, CNRS UMR 5240, Villeurbanne, France \\ ${ }^{4}$ Guangling College, Yangzhou University \\ \#Corresponding author: Dr. Likui Zhang \\ Tel: $+86-514-89795882$ \\ Fax: +86-514-87357891 \\ E-mail address: 1kzhang@yzu.edu.cn \\ Corresponding author: Prof. Zhihui Yang \\ E-mail address: bdyzh@hebau.edu.cn \\ Corresponding author: Prof. Philippe Oger \\ E-mail address: philippe.oger@insa-lyon.fr
}




\begin{abstract}
Thermococcus gammatolerans is anaerobic euryarchaeon which grows optimally at $88^{\circ} \mathrm{C}$ and its genome encodes a Family B DNA polymerase (Tga PolB). Herein, we cloned the gene of Tga PolB, expressed and purified the gene product, and characterized the enzyme biochemically. The recombinant Tga PolB can efficiently synthesize DNA at high temperature, and retain $93 \%$ activity after heated at $95^{\circ} \mathrm{C}$ for $1.0 \mathrm{hr}$, suggesting that the enzyme is thermostable. Furthermore, the optimal $\mathrm{pH}$ for the enzyme activity was measured to be 7.0-9.0. Tga PolB activity is dependent on a divalent cation, among which magnesium ion is optimal. $\mathrm{NaCl}$ at low concentration stimulates the enzyme activity but at high concentration inhibits enzyme activity. Interestingly, Tga PolB is able to efficiently bypass uracil in DNA, which is distinct from other archaeal Family B DNA pols. By contrast, Tga PolB is halted by an AP site in DNA, as observed in other archaeal Family B DNA polymerases. Furthermore, Tga PolB extends the mismatched ends with reduced efficiencies. The enzyme possesses $3^{\prime}-5^{\prime}$ exonuclease activity and this activity is inhibited by dNTPs. The DNA binding assays showed that Tga PolB can efficiently bind to ssDNA and primed DNA, and have a marked preference for primed DNA. Last, Tga PolB can be used in routine PCR.
\end{abstract}

Keywords: Archaea; DNA polymerase; DNA replication; Routine PCR 


\section{Introduction}

DNA polymerase (pol) is a ubiquitous enzyme that replicates DNA in all living cells. Since the first DNA pol was discovered and characterized from Escherichia coli in the 1950s by Arthur Kornberg, a large number of DNA pols have been biochemically and structurally characterized from diverse organisms. Currently, DNA pols have been grouped into six families: A, B, C, D, X, and Y, based on amino acid sequence similarities [1]. In addition, reverse transcriptase has been proposed as the seventh family since it can synthesize DNA [2]. Family B DNA pols have been found in bacteria, archaea, eukarya, and viruses/phages. A typical characteristic of most of Family B DNA pols is that they possess $3^{\prime}-5^{\prime}$ exonuclease activity in addition to polymerase activity [3; 4], which can remove a misincorporated nucleotide opposite a template strand, thus enhancing fidelity approximately 100 -fold.

As the third life, Archaea are a simplified version of eukarya with respect to DNA metabolism [5; 6; 7]. Currently, DNA pols of Family B, D, and Y have been found in Archaea [8]. Family B DNA pols are ubiquitous in both Euryarchaeota and Crenarchaeota, which are two major branches of Archaea. In addition to possessing five conserved motifs, archaeal Family B DNA pols have a unique uracil binding motif $[9 ; 10]$, which can recognize uracil and hypoxanthine bases derived from deamination in template DNA. Replication of uracil and hypoxanthine before repair leads to $\mathrm{GC}$ to $\mathrm{AT}$ mutation and $\mathrm{AT}$ to $\mathrm{GC}$ mutation, respectively. However, replication by archaeal Family B DNA pols would be stalled if deaminated base is encountered with these pols $[11 ; 12]$. Such an error avoidance mechanism would be expected to be evolutionary favorable for hyperthermophilic Archaea thriving in high- 
temperature environments where the rates of deamination are increased. Hence, the recognition of these pro-mutagenic lesions and the following replication stop observed in archaeal Family B DNA pols might be a specific adaptation of hyperthermophilic Archaea to their hostile environments.

As an important branch of euryarchaea, Thermococcus thrives in hightemperature environments, including deep-sea hydrothermal vents and hot springs. Increasing numbers of Thermococcus species have been isolated and identified [13]. Since the first archaeal Family B DNA pol was reported from Thermococcus litoralis [14], a dozen of archaeal Family B DNA pols have been biochemically characterized from Thermococcus species: Thermococcus $9^{\circ} \mathrm{N}-7$ [15], Thermococcuscelericrescens [16], Thermococcus fumicolans [17], Thermococcus sp. NA1 [18], Thermococcus peptonophilus [19], Thermococcus zilligii [20], Thermococcus aggregans [21], Thermococcus celer [22], Thermococcus marinus [23], Thermococcus pacificus [24], Thermococcus thioreducens [25], Thermococcuswaiotapuensis [26], and Thermococcus barophilus Ch5 [27]. All these DNA pols have been proven to be used efficiently in routine PCR.

The euryarchaeon Thermococcus gammatolerans was isolated from a hydrothermal vent located in the Gulf of California [28]. This euryarchaeon is a hyperthermophilic archaeon with an optimal growth temperature of $88^{\circ} \mathrm{C}$ which can fully withstand a $5.0 \mathrm{kGy}$ dose of gamma irradiation without loss of viability [29], and thus is the most radioresistant archaeon to date. In reason of its extreme tolerance of extreme temperatures and irradiation, it was very interesting to test whether the DNA 
polymerases of $T$. gammatolerans has any specific features in comparison to other DNA pols from this family. The genome of T. gammatolerans encodes two DNA pols, a Family B DNA pol (Tga PolB) and Family D DNA pol [29]. In this work, we cloned the Tga PolB gene, expressed its product and characterized its biochemical characteristics. The recombinant Tga PolB was found capable of bypassing uracil in a template DNA, which is distinct from other Family B archaeal DNA pols. Furthermore, biochemical characterization of Tga PolB is discussed.

\section{Materials and methods}

\subsection{Materials}

Materials were purchased from the following companies: pET-30a $(+)$, Novagen (Merck, Darmstadt, Germany); Plasmid Extraction Kit, PCR Cycle Pure Kit, and Gel Extraction Kit, Omega (Guangzhou, China); Escherichia coliDH5 $\alpha$ cells, Transgene (Beijing, China); dNTPs, T4 DNA ligase, NdeI, XhoI, and Pfu DNA pol, Thermo Fisher Scientific (Waltham, MA); Chemicals, Amresco (WA, USA).

\subsection{DNA substrates}

All the oligonucleotides used were synthesized by Sangon Company (Shanghai, China) and their sequences are listed in Table 1. Primed DNA substrates were prepared by annealing the Cy3-labeled oligonucleotide with its complementary oligonucleotides in an annealing buffer containing $20 \mathrm{mM}$ Tris- $\mathrm{Cl} \mathrm{pH} 8.0$ and 100 $\mathrm{mM} \mathrm{NaCl}$. The annealing reactions were performed at $100^{\circ} \mathrm{C}$ for $5 \mathrm{~min}$ and cooled slowly to room temperature at least 4 hours.

\subsection{Cloning of the Tga PolB encoding gene}


The TGAM_RS07365 gene encoding a Family BDNA pol of $T$. gammatolerans was amplified by Pfu DNA pol using the genomic DNA as the template in the presence of the forward primer (5'-GGG AAT TCC ATA TGC ATTCTCGATACCGACTACATC-3', the italic nucleotides represent NdeI restriction site) and the reverse primer (5'- CCG CTC GAG TCA CTT CTT CCC TTT CAC CTT CAG-3', the italic nucleotides represent XhoI restriction site).The PCR product was extracted and cleaved by NdeI and XhoI, and cloned into a pET-30a (+) vector. The sequence of the recombinant plasmid was verified by sequencing, and the confirmed plasmid was transformed into E. coli BL21 (DE3) RIL cells for expressing Tga PolB protein with a $6 \mathrm{x}$ His-tag in its C-terminal.

\subsection{Overexpression and purification of Tga PolB}

For Tga PolB protein expression, the transformant was cultured at $37^{\circ} \mathrm{C}$ in $\mathrm{LB}$ medium containing $10 \mu \mathrm{g} / \mathrm{mL}$ kanamycin and $17 \mu \mathrm{g} / \mathrm{mL}$ chloramphenicol until the $\mathrm{OD}_{600}$ reached 0.6.Then, isopropyl thiogalactoside (IPTG) was added at a final concentration of $0.8 \mathrm{mM}$ for 12 hours at room temperature to induce the expression from the recombinant plasmid.

The induced cells were harvested by centrifugation and resuspended in a $\mathrm{Ni}$ column buffer A containing $20 \mathrm{mM}$ Tris- $\mathrm{HCl} \mathrm{pH}$ 8.0, $1 \mathrm{mM}$ dithiothreitol (DTT), 500 $\mathrm{mM} \mathrm{NaCl}, 50 \mathrm{mM}$ imidazole and 10\% glycerol. The cells were immediately disrupted by ultrasonication at $4^{\circ} \mathrm{C}$. After removing cell debris by centrifugation $(16,000 \mathrm{~g})$ at $4^{\circ} \mathrm{C}$, the supernatant was heated at $70^{\circ} \mathrm{C}$ for $20 \mathrm{~min}$. The supernatant was then collected after centrifugation $(16,000 \mathrm{~g})$ at $4^{\circ} \mathrm{C}$ and was loaded onto a HisTrap FF 
column (GE Healthcare, Uppsala, Sweden). The column was eluted with $\mathrm{NCG}^{\mathrm{TM}}$ Chromatography System (Bio-Rad, Hercules, CA, USA) using a linear gradient of 50-500 mM imidazole with a Ni column buffer B containing $20 \mathrm{mM}$ Tris- $\mathrm{HCl}(\mathrm{pH}$ 8.0), $1 \mathrm{mM}$ DTT, $500 \mathrm{mM} \mathrm{NaCl}, 500 \mathrm{mM}$ imidazole and $10 \%$ glycerol. Fractions containing the His-tagged Tga PolB protein were collected and analyzed by migration on a $10 \%$ SDS-PAGE. The purified Tga PolB protein fractions were dialyzed against a storage buffer containing $50 \mathrm{mM}$ Tris- $\mathrm{HCl}(\mathrm{pH}$ 8.0), $1 \mathrm{mM}$ DTT, 50\% glycerol and $50 \mathrm{mM} \mathrm{NaCl}$, and stored at $-80^{\circ} \mathrm{C}$. The Tga PolB protein concentration was quantitated by measuring the absorbance at $280 \mathrm{~nm}$. The theoretical molar extinction coefficient of the enzyme protein is predicted to be $122,300 \mathrm{M}^{-1} \mathrm{~cm}^{-1}$.

\subsection{Polymerase assays}

The standard reaction mixture $(10 \mu \mathrm{L})$ contained 50 nM Tga PolB, $200 \mathrm{nM}$ Cy3labeled primed DNA substrate (p22/t59), 20 mM Tris- $\mathrm{HCl}$ pH8.0, 2 mM DTT, 100 $\mu \mathrm{g} / \mathrm{mL}$ BSA,2 $\mathrm{mM} \mathrm{MgCl}_{2}$, and $200 \mu \mathrm{M}$ dNTPs. The polymerization reactions were performed for $15 \mathrm{~min}$ at $65^{\circ} \mathrm{C}$. The polymerized product was analyzed by electrophoresis in a $15 \%$ polyacrylamide gel containing $8 \mathrm{M}$ urea. The gel was visualized with a Molecular Image analyzer (Bio-Rad). ImageQuant software was used for quantitative analysis. All polymerase experiments were repeated three times.

\section{6. $3^{\prime}-5$ 'exonuclease assays}

The standard reaction mixture $(10 \mu \mathrm{L})$ contained an indicated amount of Tga PolB, 200 nM Cy3-labeledssDNA, 20 mM Tris-HCl pH 8.0, 2 mM DTT, $100 \mu \mathrm{g} / \mathrm{mL}$ BSA, and $2 \mathrm{mM} \mathrm{MgCl} 2$. Reactions were carried out for $15 \mathrm{~min}$ at $65^{\circ} \mathrm{C}$. The cleaved 
products were subjected to electrophoresis in a polyacrylamide urea gel as described above. The gel was visualized with a Molecular Image analyzer (Bio-Rad). ImageQuant software was used for quantitative analysis. All exonuclease experiments were repeated three times.

\subsection{Electrophoretic mobility shift assays (EMSA)}

200 nM Cy3-labeled ssDNA or primed DNA were incubated with Tga PolB with varied concentrations in $20 \mathrm{mM}$ Tris- $\mathrm{HCl} \mathrm{pH} 8.0,1 \mathrm{mM}$ DTT and $8 \%$ glycerol at room temperature for $10 \mathrm{~min}$. The retarded product was analyzed by electrophoresis in a $4 \%$ native polyacrylamide gel in $0.1 \times$ TBE buffer and visualized with a Molecular Image analyzer (Bio-Rad). ImageQuant software was used for quantitative analysis. All DNA-binding experiments were repeated three times.

\subsection{PCR amplification assays}

To determine whether Tga PolB can be used in routine PCR, we performed PCR reactions containing $50 \mathrm{mM}$ Tris- $\mathrm{Cl} \mathrm{pH} 8.0,0.1 \mathrm{mg} / \mathrm{ml}$ BSA, $5 \mathrm{mM} \mathrm{Mg}{ }^{2+}, 50 \mathrm{mM}$ $\mathrm{NaCl}$ and $130 \mathrm{nM}$ Tga PolB to amplify the gene TBCH5v1_0629 (744 bp) using the genomic DNA of Thermococcus barophilus Ch5 as a template and PCR primers described in our previous publication [30]. The cycling of PCR reactions was performed as follows: one initial denaturation at $98^{\circ} \mathrm{C}$ for $5 \mathrm{~min}$ followed by 30 cycles of $95^{\circ} \mathrm{C}$ for $30 \mathrm{~s}, 50^{\circ} \mathrm{C} 30 \mathrm{~s}$ and $72{ }^{\circ} \mathrm{C} 1 \mathrm{~min}$, and the final step was $72^{\circ} \mathrm{C} 10 \mathrm{~min}$. PCR products were resolved by electrophoresisin a $0.8 \%$ standard agarose gel.

\section{Results}

\subsection{Cloning, expression and purification of Tga PolB protein}


The genome of $T$. gammatolerans encodes a Family B DNA polymerase. To characterize Tga PolB biochemically, its gene was cloned into a pET30a $(+)$ expression vector, and overexpressed in E.coli. The recombinant Tga PolB protein was purified to near homogeneity after Ni-column affinity purification (Fig. 1A). The purified protein displayed an approximate MW of $90 \mathrm{kDa}$ (Fig. 1A), which correlates with the deduced amino acid sequences.

Using the primed DNA (p22/t59), we determined the polymerase activity of the purified Tga PolB protein using concentrations ranging from 1 to $500 \mathrm{nM}$. As shown in Fig.1B, the full length product was gradually created with increasing Tga PolB concentrations at $65^{\circ} \mathrm{C}$, and maximal activity ( $>90$ polymerization percentage) was obtained at $\geq 20 \mathrm{nM}$, suggesting that the enzyme is able to efficiently synthesize DNA at high temperature.

The genome of E.coli encodes five DNA pols that can synthesize DNA, which might interfere with our above observations [31]. To rule out this possibility, we prepared the E.coli cell extract with the empty pET-30a $(+)$ plasmid as described for preparation of the recombinant pET30a $(+)$ plasmid with the Tga PolB gene. We used the cell extract to perform above DNA synthesis reactions, and found that no synthesized product was observed (data not shown). Thus, the possibility of contamination of E.coli DNA pols was removed, thereby indirectly confirming that Tga PolB can synthesize DNA at high temperature.

\subsection{Biochemical characterization of Tga PolB}

The biochemical characteristics of DNA synthesis by Tga PolB, which includes 
thermostability, the optimal $\mathrm{pH}$, divalent cation availability, salt adaptation and dNTPs availability, were investigated using the primed DNA described above as the substrate. Considering the instability of primed duplex used in this work at $>65^{\circ} \mathrm{C}$, we performed DNA synthesis reaction of Tga PolB at $<65^{\circ} \mathrm{C}$. As shown in Fig. S1, the enzyme is capable of synthesizing DNA at increasing temperatures ranging from $25^{\circ} \mathrm{C}$ to $65^{\circ} \mathrm{C}$ with varied efficiencies High synthesis efficiency $(99 \%)$ was observed from $45^{\circ} \mathrm{C}$ to $65^{\circ} \mathrm{C}$, further confirming that Tga PolB can replicate DNA at high temperature.

To investigate its thermo-tolerance, $500 \mathrm{nM}$ Tga PolB was heated at varying temperatures for different times, and the heated enzyme $(50 \mathrm{nM})$ was used to perform DNA synthesis reactions at $65^{\circ} \mathrm{C}$. Our results showed that the enzyme is able to fully withstand $95^{\circ} \mathrm{C}$ for at least $1.0 \mathrm{hr}$, retaining a $93 \pm 2.6 \%$ activity (Fig. 2A). After 2 hours at $95^{\circ} \mathrm{C}$, the enzyme retained ca. $20 \pm 2.1 \%$ activity. Thus, these observations confirm that, as expected from DNA pols from other Thermococcus, Tga PolB is a thermostable DNA pol.

To investigate the effect of $\mathrm{pH}$ on Tga PolB activity, we reduced enzyme concentrations to be $15 \mathrm{nM}$ in DNA synthesis. As shown in Fig. 2B, the enzyme could synthesize DNA in a broad $\mathrm{pH}$ range from 5.0 to 10.0 , at which the activity begins to be altered. No product is synthesized at $\mathrm{pH}=11$. The maximal synthesis activity was observed between $\mathrm{pH} 7.0$ and 9.0, but our test did not allow having more precision on the effective optimum.

It is well-known that DNA pols utilize a divalent cation to synthesize DNA. To 
investigate the effect of a divalent cation on Tga PolB activity, we reduced enzyme concentrations to be $15 \mathrm{nM}$ in DNA synthesis. As expected, no product was observed in DNA synthesis by Tga PolB without a divalent cation or with EDTA (Fig. 2C). Only two divalent ions, $\mathrm{Mg}^{2+}$ and $\mathrm{Mn}^{2+}$, could restore DNA pol activity to the enzyme. The polymerization percentage of Tga PolB was estimated to be $72 \pm 5.7 \%$ and $33 \pm$ 7.1\% in the presence of $\mathrm{Mg}^{2+}$ and $\mathrm{Mn}^{2+}$, respectively, demonstrating that similarly to other Thermococcus DNA PolB, DNA synthesis activity of Tga PolB is dependent on a divalent cation. Thus, $\mathrm{Mg}^{2+}$ is the preferred ion for polymerization activity of Tga PolB.

We investigated the salt tolerance of the enzyme from 0 to $600 \mathrm{mM}$ by using 15 nM enzyme in DNA synthesis reactions. In absence of $\mathrm{NaCl}$, Tga PolB displayed $67 \pm$ $2.2 \%$ polymerization activity (Fig. 2D). From 50 to $200 \mathrm{mM} \mathrm{NaCl}$, the activity was higher than $90 \%$, but it was significant reduced at $\mathrm{NaCl}$ concentrations above $400 \mathrm{mM}$. Thus, $\mathrm{NaCl}$ is required for optimal Tga PolB activity. But, enzyme activity was inhibited by $400 \mathrm{mM} \mathrm{NaCl}$, and no synthesis was observed at $600 \mathrm{mM} \mathrm{NaCl}$.

\subsection{Effect of dNTPs on the balance of the polymerase and exonuclease activity of}

\section{Tga PolB}

Most of Family B DNA pols, including the members from Archaea, possess 3'-5' exonuclease activity in addition to 5'-3' polymerase activity. To examine whether Tga PolB has exonuclease activity, we used ssDNA as a substrate. As expected, we found that Tga PolB started to degrade DNA when adding $5 \mathrm{nM}$ enzyme to the exonuclease reaction, and exonuclease activity increased with increasing enzyme concentration 
(Fig. 3A). Maximal exonuclease efficiency ( $>90 \%)$ was obtained when for concentrations of $15 \mathrm{nM}$ Tga PolB and higher. Furthermore, DNA products with various sizes were created in the presences of varied concentrations of Tga PolB.

Next, we investigated the effect of dNTPs on the balance of the polymerase activity and exonuclease activity of Tga PolB. We designated Exo/Pol as the effect of dNTPs concentration on the balance of exonuclease activity and polymerase activity. As the the dNTPs concentrations increased, the values of Exo/Pol decreased, suggesting that dNTPs concentrations are favor in polymerase activity. At $4.0 \mu \mathrm{M}$ dNTPs, the values of Exo/Pol reached 0.07 (Fig. 3B), indicating that Tga PolB exhibits extremely weak exonuclease activity in the presence of $4.0 \mu \mathrm{M}$ dNTPs. Thus, dNTPs stimulates Tga PolB to synthesize DNA rather than degrade DNA.

\subsection{Mismatch extension of Tga PolB}

We determined mismatch the extension efficiency of Tga PolB by using primed DNA with a match end $(\mathrm{C} / \mathrm{G})$ and primed DNA with a mismatch end $(\mathrm{C} / \mathrm{A}, \mathrm{A} / \mathrm{G}$ and T/G) as substrates. As shown in Fig. 4, no matter what concentration of Tga PolB was used in polymerase reactions, $>95 \%$ polymerization percentage was observed during DNA synthesis by Tga PolB when using the primed DNA with a match as the substrate. However, Tga PolB displayed only about $18 \pm 1.5 \%, 15 \pm 2.8 \%$ and $14 \pm$ $4.3 \%$ activity for extending $\mathrm{A} / \mathrm{G}, \mathrm{G} / \mathrm{G}$ and $\mathrm{T} / \mathrm{G}$ mismatch at $20 \mathrm{nM}$, respectively. Furthermore, at $50 \mathrm{nM}$, the efficiencies of the enzyme were still lower than for matched DNA, with $83 \pm 5.7 \%, 72 \pm 7.8 \%$ and $77 \pm 0.8 \%$ for extending $\mathrm{A} / \mathrm{G}, \mathrm{G} / \mathrm{G}$ and $\mathrm{T} / \mathrm{G}$ mismatch at $50 \mathrm{nM}$, respectively. Only at $200 \mathrm{nM}$ the enzyme displayed full 
efficiency for extending mismatched DNA. Overall, these results suggested that Tga PolB has a low efficiency to extend mismatched DNA, although capable to extend it at high DNA/protein ratios.

\subsection{Bypass activity of uracil and AP in DNA by Tga PolB}

Archaeal Family B DNA pols can recognize uracil in DNA, which results in polymerization arrest. Using uracil-containing primed DNA as the substrate, we tested this ability in Tga PolB. Note that the full length template DNA is 59 mer and uracil in the template DNA is located at 42 mer described in Table 1. As shown in Fig. 5, the full length product was observed at $200 \mathrm{nM}$ Tga PolB in the control reaction using the normal primed DNA as the substrate. Compared with the control reaction, two products corresponding to 42 mer (partial length) and 59 mer (full length) were synthesized by $200 \mathrm{nM}$ Tga PolB using the uracil-containing primed DNA as the substrate. Furthermore, more synthesized full length product than partial length product was created by Tga PolB, suggesting that this pol can bypass the uracil of the DNA template, which is a distinct feature from typical archaeal Family B DNA pols.

Since Tga PolB could bypass U bases in its DNA template, we tested whether it could also bypass AP sites in DNA. Like uracil-containing DNA, the AP site in the full length template DNA (59mer) is also located in 42 mer position. By using APcontaining primed DNA as a substrate, we conducted DNA synthesis by Tga PolB. As shown in Fig. 5, only one band corresponding to 42 mer product was observed by Tga PolB, which is sharply inconsistent with the observation of the replication of uracil containing DNA by this pol. In contrast, no full length product was synthesized by 
Tga PolB, suggesting that this pol cannot bypass AP sites, as observed in other archaeal Family B DNA Pols.

\subsection{DNA Binding by Tga PolB}

Since Tga PolB can degrade ssDNA and extend primed DNA with both matched and mismatched ends, we employed the EMSA to determine whether Tga PolB is able to bind DNA. We incubated ssDNA, primed DNA and primed DNA with a mismatch (T/G) with Tga PolB at varying concentrations, respectively. As shown in Fig. 6A, the binding of free ssDNA substrate increased gradually with increasing Tga PolB concentrations. No ssDNA binding was observed at $100 \mathrm{nM}$ and maximal binding was observed at $500 \mathrm{nM}$.

dsDNA binding also increased as Tga PolB concentration increased, from $49 \pm$ $5.0 \%, 80 \pm 4.8 \%$, and $86 \pm 3.6 \%$ at $100 \mathrm{nM}, 200 \mathrm{nM}$ and $300 \mathrm{nM}$ enzyme (Fig. 6B). At higher concentrations $(>400 \mathrm{nM})$, the binding percentages reached $>90 \%$ and reached its maximum ( $97 \%)$ at $500 \mathrm{nM}$. Thus, Tga PolB has a slightly higher affinity for primed DNA binding than for ssDNA binding. Tga PolB binding to primed DNA is not affected by the presence of mismatches (Fig. 6C).

\subsection{PCR amplification of Tga PolB}

Last, we investigated whether or not Tga PolB can be used for routine PCR to amplify DNA. Using the genomic DNA of $T$. barophilus Ch5 as a template, we performed the PCR reaction to amplify the UDG247 gene with Tga PolB. As shown in Fig. 7, the PCR product was clearly created by Tga PolB, corresponding to $744 \mathrm{bp}$, thus suggesting that this Pol can be employed in routine PCR. 


\section{Discussion}

In this work, we characterized biochemically the Family B DNA pol from the hyperthermophilic and radioresistant euryarchaeon T. gammatolerans, and revealed that Tga PolB can replicate DNA at high temperature. Consistent with other Thermococcus DNA pol homologues, Tga PolB displays similar biochemical characteristics for DNA synthesis. As expected, Tga PolB can be used to amplify DNA by routine PCR reaction, suggesting that this Pol also resembles other Thermococcus DNA pols. Interestingly, Tga PolB has extraordinary properties that are distinct from other archaeal Family B DNA pols.

Crystal structures of archaeal Family B DNA pols demonstrate that they possess uracil recognition pocket $[9 ; 32]$, thus allowing the replication to be stopped when these DNA pols encounter a uracil in DNA template. Biochemical data provide strong support for the 'read-ahead' mechanism. Archaeal B family DNA polymerases, such as Pfu DNA pol, can recognize uracil in DNA template strand during DNA synthesis and will be stalled 4 bp upstream of a template uracil. Thereby preventing $G: C \rightarrow A: T$ mutation [33]. Although this PolB can bypass uracil in DNA template with low efficiency, the hyperthermoacidophilic crenarchaeon Sulfolobus solfataricus DNA polB1 (Sso PolB1) also has similar read-ahead behavior [34]. Furthermore, Pfu PolB displays much weaker ability to bypass uracil in DNA template than Sso PolB1 [34] . However, we demonstrated that Tga PolB can efficiently synthesize DNA despite encountering uracil in DNA template, which differs from other Thermococcales enzymes such as Pfu PolB, and Sso PolB1. Consistent with Sso PolB1, Tga PolB 
cannot continue to replicate DNA when encountering an AP lesion in DNA template, consistent with other archaeal Family B DNA pols $[34 ; 35]$.

As DNA polymerase substrate, deoxynucleotide triphosphates affect the exonuclease/polymerase balance of a DNA polymerase. It has been reported that dNTPs stimulate polymerase activity of a DNA polymerase and suppress its exonuclease activity. However, different DNA polymerases display distinct sensitivity to the dNTP inhibition. In this study, we demonstrate that Tga PolB is capable of extending primer at a low level $(2 \mu \mathrm{M})$ of dNTPs, which is consistent with Sso polB1 [36]. In contrast to Sso PolB1, which retains its exonuclease activity up to $600 \mu \mathrm{M}$ dNTPs, Tga PolB already lacks an exonuclease activity at $5 \mu \mathrm{M}$ dNTPs [36].

A replicative DNA polymerase has polymerase activity and $3^{\prime}-5^{\prime}$ exonuclease activity, and is in favor of exonuclease activity when encountering a mismatched primer end to ensure high fidelity of DNA replication. In this study, we show that Tga PolB is able to efficiently extend primer with a correct pair end at $20 \mathrm{nM}$. However, Tga PolB displays significantly reduced extension efficiencies for primers with incorrected pair ends at $20 \mathrm{nM}$, which may be caused by the exonuclease activity of Tga PolB that can remove the mismatched 3' nucleotide to generate a match base pair. Thus, Tga PolB might be in favorable for the exonuclease activity for removing incorrected nucleotide when encountering a mismatched pair end and then start to synthesize DNA after proofreading.

Last, we also show that Tga PolB displays higher affinity for binding primed DNA than for binding ssDNA at $<300 \mathrm{nM}$. Furthermore, two bands corresponding to 
primed DNA binding appeared while only band corresponding to ssDNA binding of was observed at both $200 \mathrm{nM}$ and $300 \mathrm{nM}$ Tga PolB. We proposed that one primed DNA molecular would be bound with two Tga PolB molecular whereas one Tga PolB molecular might bind one ssDNA molecular. Overall, Tga PolB has distinct binding patterns for primed DNA and ssDNA.

\title{
Conclusion
}

In summary, we present the biochemical characteristics of the Family B DNA pol from the hyperthermophilic and radioresistant $T$. gammatolerans. We demonstrate that the recombinant Tga PolB possesses polymerase activity for DNA synthesis and exonuclease activity for removing misincorporated nucleotide. Surprisingly, Tga PolB can replicate DNA when encountering uracil in DNA template, which is sharply contrasted with other archaeal Family B DNA pols. However, this pol can be stalled by an AP site in DNA. Furthermore, dNTPs stimulate the polymerase activity and inhibit the exonuclease activity of Tga PolB. Tga PolB can bind to primed DNA with higher efficiencies than to ssDNA at low concentration, and also display distinct binding patterns for primed DNA and ssDNA. Last, Tga PolB can be used in routine PCR.

\begin{abstract}
Acknowledgement
We thank Prof. Fabrice Confalonieri at Radiorésistance des Bactéries et des Archaea Université Paris Sud for providing T. gammatolerans genomic DNA.
\end{abstract}

\section{Author contributions}

LZ and ZY designed experiments; DJ, HS, MW and QG performed experiments; 


\title{
Conflict of interests
}

\begin{abstract}
All authors declare that there is no conflict of interests regarding the publication of this paper.
\end{abstract}

\section{Funding}

Research in Dr. Likui Zhang's laboratory was supported by the Provincial Natural Science Foundation of Jiangsu (No. BK20191219), the Academic Leader of Middle and Young People of Yangzhou University Grant and State Key Laboratory of Microbial Metabolism, Shanghai JiaoTong University (No. MMLKF18-05). Research in Prof. Zhihui Yang's laboratory was supported by the Earmarked Fund for Modern Agro-industry Technology Research System in Hebei Province, China (HBCT2018080205).

\section{Figure legends}

Fig. 1. Tga PolB is able to synthesize DNA at $65^{\circ} \mathrm{C}$. A. the overexpression and purification of the recombinant Tga PolB protein. B. DNA synthesis of Tga PolB at $65^{\circ} \mathrm{C}$. The DNA synthesis reactions were performed by Tga PolB at $65^{\circ} \mathrm{C}$ in the presence of varied concentrations. The synthesized DNA products were analyzed by running a denaturing polyacrylamide gel. CK: the reaction without the enzyme.

Fig. 2. Biochemical characterization of Tga PolB. A. the thermo-tolerance of the enzyme; B. the optimal $\mathrm{pH}$ of the enzyme activity; C. the effects of divalent cations on the enzyme activity; $\mathrm{D}$. the effect of $\mathrm{NaCl}$ on the enzyme activity. The DNA synthesis reactions were performed at $65^{\circ} \mathrm{C}$. The synthesized DNA products were 
analyzed by a denaturing polyacrylamide gel. CK in panels A, B and D, and CK1 in panels $\mathrm{C}$ : the reaction without the enzyme; CK2 in panel C: the reaction without a divalent cation.

Fig. 3. Inhibition of exonuclease activity of Tga PolB by dNTPs substrate. A. the exonuclease activity of Tga PolB. Tga PolB with varied concentrations was employed to perform exonuclease reactions by using the ssDNA as the substrate at $65^{\circ} \mathrm{C}$. The cleaved DNA products were analyzed by a denaturing polyacrylamide gel. B. the effect of dNTPs substrate on the polymerase and exonuclease activities of Tga PolB. The coupled polymerase and exonuclease activities of Tga PolB were performed at $65^{\circ} \mathrm{C}$ in the presence of dNTPs with varied concentrations. The reaction products were analyzed by a denaturing polyacrylamide gel. CK: the reaction without the enzyme.

Fig. 4. Mismatch extension by Tga PolB. The match DNA (C:G) and mismatch DNA (A:G, G:G and $T: G)$ were employed as the substrates in the DNA synthesis reactions catalyzed by Tga PolB $(20,50$ and $200 \mathrm{nM})$ at $65^{\circ} \mathrm{C}$. The synthesized DNA products were analyzed by running a denaturing polyacrylamide gel. CK: the reaction without the enzyme.

Fig. 5. Bypass analysis of uracil and AP in DNA by Tga PolB. The uracil- and APcontaining primed DNA were employed as the substrates in the DNA synthesis reactions catalyzed by $200 \mathrm{nM}$ Tga PolB at $65^{\circ} \mathrm{C}$. The synthesized DNA products were analyzed by running a denaturing polyacrylamide gel. CK: the reaction without the enzyme. 
Fig. 6. DNA binding assays of Tga PolB. $200 \mathrm{nM}$ ssDNA and primed DNA were incubated with Tga PolB with varied concentrations at room temperature, respectively. The retarded DNA products were analyzed by a native polyacrylamide gel. A. binding ssDNA; B. binding normal primed DNA; C. binding primed DNA with a mismatch (T/G). CK: the binding reaction without the enzyme.

Fig. 7. PCR amplification of Tga PolB. M: DNA marker; CK: the PCR reaction without enzyme. 


\section{References}

[1]. P.M. Burgers, E.V. Koonin, E. Bruford, L. Blanco, K.C. Burtis, M. Christman, et al, Eukaryotic DNA polymerases: proposal for a revised nomenclature. J Biol Chem 276 (2001) 43487-90.

[2]. S.J. Garforth, R.A. Domaoal, C. Watula, M.J. Landau, A.J. Meyer, K.S. Anderson, V.R. Prasad, K65R and K65A substitutions in HIV-1 reverse transcriptase enhance polymerase fidelity by decreasing both dNTP misinsertion and mispaired primer extension efficiencies. J Mol Biol 401 (2010) 33-44.

[3]. J. Wang, A.K. Sattar, C.C. Wang, J.D. Karam, W.H. Konigsberg, T.A. Steitz, Crystal structure of a pol alpha family replication DNA polymerase from bacteriophage RB69. Cell 89 (1997) 1087-99.

[4]. K.P. Hopfner, A. Eichinger, R.A. Engh, F. Laue, W. Ankenbauer, R. Huber, B. Angerer, Crystal structure of a thermostable type B DNA polymerase from Thermococcus gorgonarius. Proc Natl Acad Sci U S A 96 (1999) 3600-5.

[5]. D.R. Edgell, W.F. Doolittle, Archaea and the origin(s) of DNA replication proteins. Cell 89 (1997) 995-8.

[6]. G.J. Olsen, C.R. Woese, Archaeal genomics: an overview. Cell 89 (1997) 9914.

[7]. E.R. Barry, S.D. Bell, DNA replication in the archaea. Microbiol Mol Biol Rev 70 (2006) 876-87.

[8]. L. Zhang, M. Kang, J. Xu, Y. Huang, Archaeal DNA polymerases in 
biotechnology. Appl Microbiol Biotechnol 99 (2015) 6585-97.

[9]. S.J. Firbank, J. Wardle, P. Heslop, R.J. Lewis, B.A. Connolly, Uracil recognition in archaeal DNA polymerases captured by X-ray crystallography. J Mol Biol 381 (2008) 529-39.

[10]. M.J. Fogg, L.H. Pearl, B.A. Connolly, Structural basis for uracil recognition by archaeal family B DNA polymerases. Nat Struct Biol 9 (2002) 922-7.

[11]. R.S. Lasken, D.M. Schuster, A. Rashtchian, Archaebacterial DNA polymerases tightly bind uracil-containing DNA. J Biol Chem 271 (1996) 17692-6.

[12]. G. Shuttleworth, M.J. Fogg, M.R. Kurpiewski, L. Jen-Jacobson, B.A. Connolly, Recognition of the pro-mutagenic base uracil by family B DNA polymerases from archaea. J Mol Biol 337 (2004) 621-34.

[13]. P.M. Oger, Complete genome sequences of 11 type species from the Thermococcus genus of hyperthermophilic and piezophilic archaea. Genome Announc 6 (2018).

[14]. P. Mattila, J. Korpela, T.Tenkanen, K. Pitkanen, Fidelity of DNA synthesis by the Thermococcus litoralis DNA polymerase--an extremely heat stable enzyme with proofreading activity. Nucleic Acids Res 19 (1991) 4967-73.

[15]. M.W. Southworth, H. Kong, R.B. Kucera, J. Ware, H.W. Jannasch, F.B. Perler, Cloning of thermostable DNA polymerases from hyperthermophilic marine Archaea with emphasis on Thermococcus sp. 9 degrees N-7 and mutations affecting 3'-5' exonuclease activity. Proc Natl Acad Sci U S A 93 (1996) 5281- 
5.

[16]. K.P. Kim, S.S. Cho, K.K. Lee, M.H. Youn, S.T. Kwon, Improved thermostability and PCR efficiency of Thermococcus celericrescens DNA polymerase via site-directed mutagenesis. J Biotechnol 155 (2011) 156-63.

[17]. M.A. Cambon-Bonavita, P. Schmitt, M. Zieger, J.M. Flaman, F. Lesongeur, G. Raguenes, et al, Cloning, expression, and characterization of DNA polymerase I from the hyperthermophilic archaea Thermococcus fumicolans. Extremophiles 4 (2000)215-25.

[18]. Y.J. Kim, H.S. Lee, S.S. Bae, J.H. Jeon, J.K. Lim, Y. Cho, et al, Cloning, purification, and characterization of a new DNA polymerase from a hyperthermophilic archaeon, Thermococcus sp. NA1. J Microbiol Biotechnol 17 (2007) 1090-7.

[19]. J.I. Lee, Y.J. Kim, H. Bae, S.S. Cho, J.H. Lee, S.T. Kwon, Biochemical properties and PCR performance of a family B DNA polymerase from hyperthermophilic Euryarchaeon Thermococcus peptonophilus. Appl Biochem Biotechnol 160 (2010) 1585-99.

[20]. K. Griffiths, S. Nayak, K. Park, D. Mandelman, B. Modrell, J. Lee, et al, New high fidelity polymerases from Thermococcus species. Protein Expr Purif 52 (2007) 19-30.

[21]. K. Bohlke, F.M. Pisani, C.E. Vorgias, B. Frey, H. Sobek, M. Rossi, G. Antranikian, PCR performance of the B-type DNA polymerase from the thermophilic euryarchaeon Thermococcus aggregans improved by mutations 
in the Y-GG/A motif. Nucleic Acids Res 28 (2000) 3910-7.

[22]. K.P. Kim, H. Bae, I.H. Kim, S.T. Kwon, Cloning, expression, and PCR application of DNA polymerase from the hyperthermophilic archaeon, Thermococcus celer. Biotechnol Lett 33 (2011) 339-46.

[23]. H. Bae, K.P. Kim, J.I. Lee, J.G. Song, E.J. Kil, J.S. Kim, S.T. Kwon, Characterization of DNA polymerase from the hyperthermophilic archaeon Thermococcus marinus and its application to PCR. Extremophiles 13 (2009) 657-67.

[24]. H. Ppyun, I. Kim, S.S. Cho, K.J. Seo, K. Yoon, S.T. Kwon, Improved PCR performance using mutant Tpa-S DNA polymerases from the hyperthermophilic archaeon Thermococcus pacificus. J Biotechnol 164 (2013) 363-370.

[25]. D. Marsic, J.M. Flaman, J.D. Ng, New DNA polymerase from the hyperthermophilic marine archaeon Thermococcus thioreducens. Extremophiles 12 (2008) 775-788.

[26]. S.S. Cho, K.P. Kim, K.K. Lee, M.H. Youn, S.T. Kwon, Characterization and PCR application of a new high-fidelity DNA polymerase from Thermococcus waiotapuensis. Enzyme Microb Technol 51 (2012) 334-41.

[27]. K.M. Kwon, S.G. Kang, T.G. Sokolova, S.S. Cho, Y.J. Kim, C.H. Kim, S.T. Kwon, Characterization of a family B DNA polymerase from Thermococcus barophilus $\mathrm{Ch} 5$ and its application for long and accurate PCR. Enzyme Microb Technol 86 (2016) 117-26. 
[28]. E. Jolivet, S. L'Haridon, E. Corre, P. Forterre, D. Prieur, Thermococcus gammatolerans sp nov., a hyperthermophilic archaeon from a deep-sea hydrothermal vent that resists ionizing radiation. Int J Syst Evol Microbiol 53 (2003) 847-851.

[29]. Y. Zivanovic, J. Armengaud, A. Lagorce, C. Leplat, P. Guerin, M. Dutertre, et al, Genome analysis and genome-wide proteomics of Thermococcus gammatolerans, the most radioresistant organism known amongst the Archaea. Genome Biol 10 (2009).

[30]. H. Shi, Q. Gan, D. Jiang, Y. Wu, Y. Yin, H. Hou, et al, Biochemical characterization and mutational studies of a thermostable uracil DNA glycosylase from the hyperthermophilic euryarchaeon Thermococcus barophilus Ch5. Int J Biol Macromol 134 (2019) 846-855.

[31]. M. Garcia-Diaz, K. Bebenek, Multiple functions of DNA polymerases. CRC Crit Rev Plant Sci 26 (2007) 105-122.

[32] C. Savino, L. Federici, K.A. Johnson, B.Vallone, V. Nastopoulos, M. Rossi, et al, Insights into DNA replication: the crystal structure of DNA polymerase B1 from the archaeon Sulfolobus solfataricus. Structure 12 (2004) 2001-8.

33. J. Wardle, P.M.J. Burgers, I.K.O. Cann, K. Darley, P. Heslop, E. Johansson, et al, Uracil recognition by replicative DNA polymerases is limited to the archaea, not occurring with bacteria and eukarya. Nucleic Acids Res 36 (2008) 705-711.

34. P. Gruz, M. Shimizu, F.M. Pisani, M. De Felice, Y. Kanke, T. Nohmi, 
35. S.K. Jozwiakowski, B.J. Keith, L. Gilroy, A.J. Doherty, B.A. Connolly, An archaeal family-B DNA polymerase variant able to replicate past DNA damage: occurrence of replicative and translesion synthesis polymerases within the B family. Nucleic Acids Res 42 (2014) 9949-63.

36. H.Q. Lou, Z.H. Duan, T. Sun, L. Huang, Cleavage of double-stranded DNA by the intrinsic $3^{\prime}-5$ ' exonuclease activity of DNA polymerase B1 from the hyperthermophilic archaeon Sulfolobus solfataricus at high temperature. FEMS Microbiol Lett 231 (2004) 111-117. 
Table 1 Sequences of the oligonucleotides used in this work

\begin{tabular}{ll}
\hline Name & Sequence $\left(5^{\prime}-3^{\prime}\right)$ \\
\hline p22C* & CAG TGA ATT CGA GCT CGG TAC C \\
p22A* & CAG TGA ATT CGA GCT CGG TAC A \\
p22G* & CAG TGA ATT CGA GCT CGG TAC G \\
p22T* & CAG TGA ATT CGA GCT CGG TAC T \\
t59 & GCT TGC ATG CCT GCA GGT CGA CTC TAG AGG ATC CCC \\
& GGG TAC CGA GCT CGA ATT CAC TG \\
t59U & GC TTG CAT GCC TGC AGG UCGA CTC TAG AGG ATC CCC \\
& GGG TAC CGA GCT CGA ATT CAC TG \\
t59AP & GCT TGC ATG CCT GCA GGAPCGA CTC TAG AGG ATC CCC \\
& GGG TAC CGA GCT CGA ATT CAC TG \\
\hline
\end{tabular}

*indicates the Cy3-labeling at 5' end of primers (p22C, p22A, p22G and p22T).

The underlined base is used to prepare uracil (U)- and AP (Apurinc/apyrimidinic)containing dsDNA. 


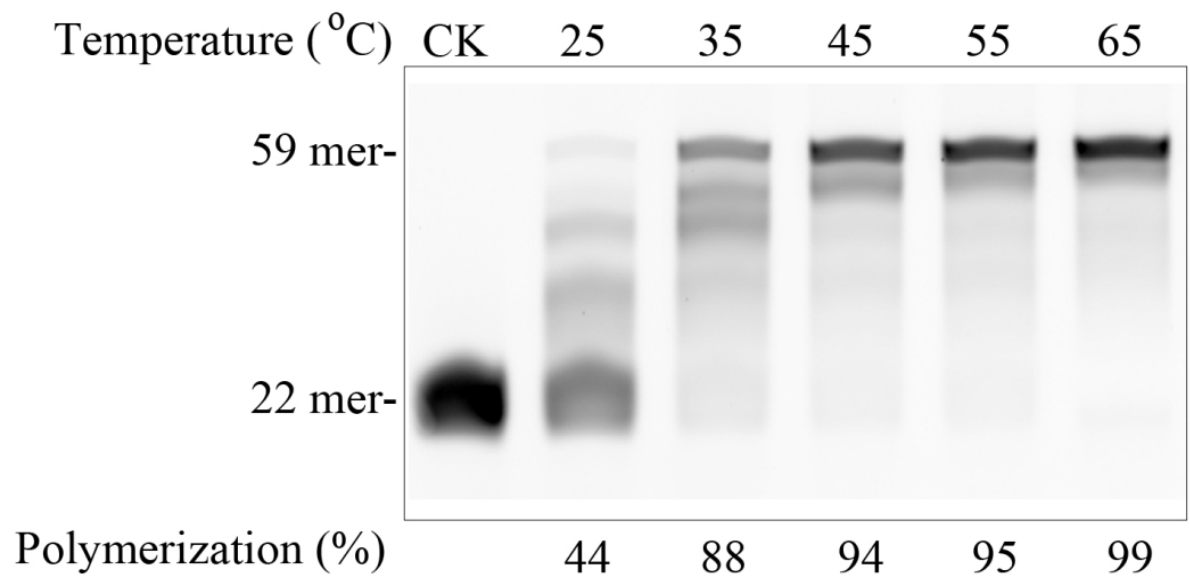

Fig. s1. DNA synthesis of Tga PolB at different temperatures. The DNA synthesis reactions were performed by $50 \mathrm{nM}$ Tga PolB at different temperatures. The synthesized DNA products were analyzed by running a denaturing polyacrylamide gel. CK: the reaction without the enzyme. 
A

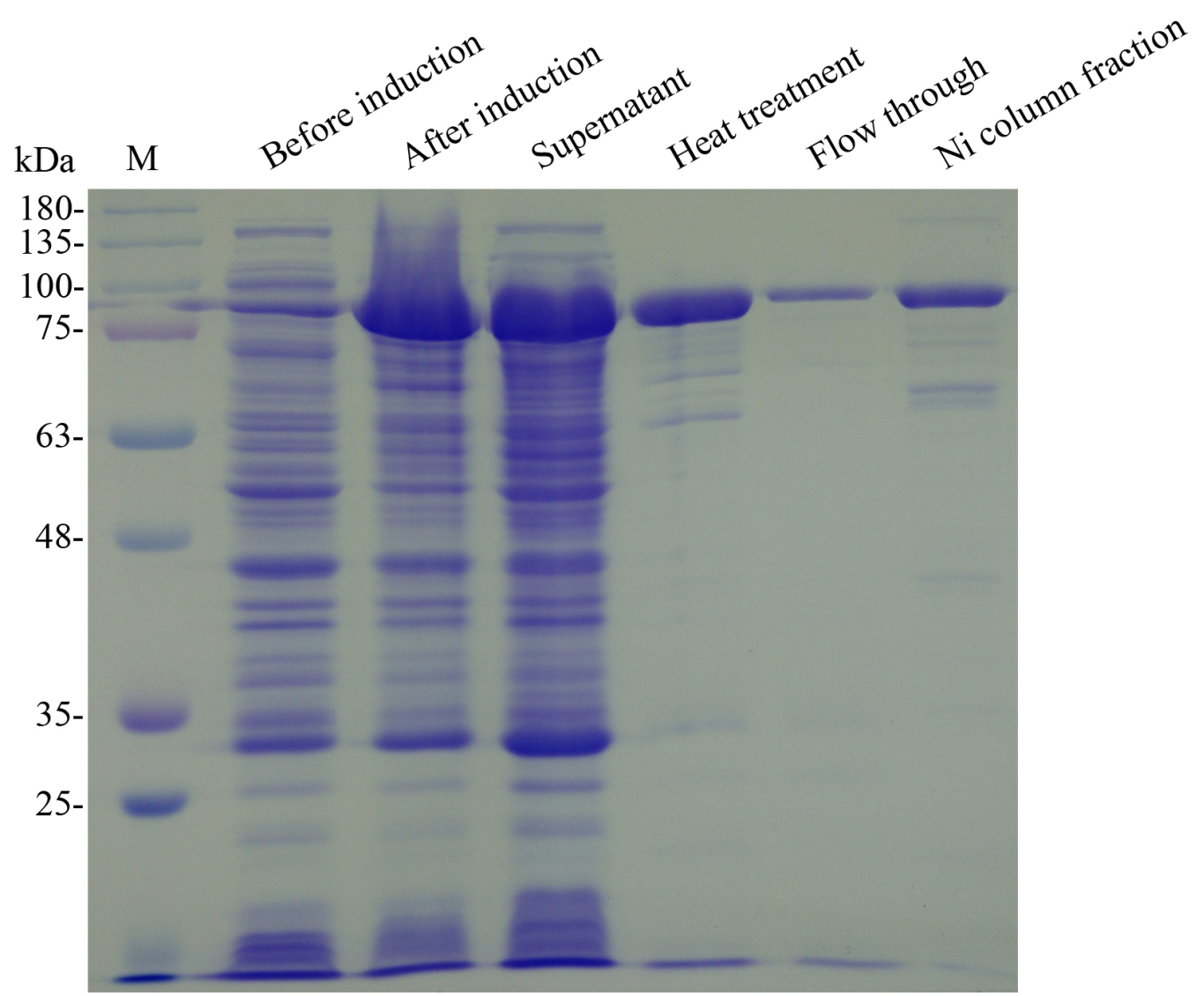

B

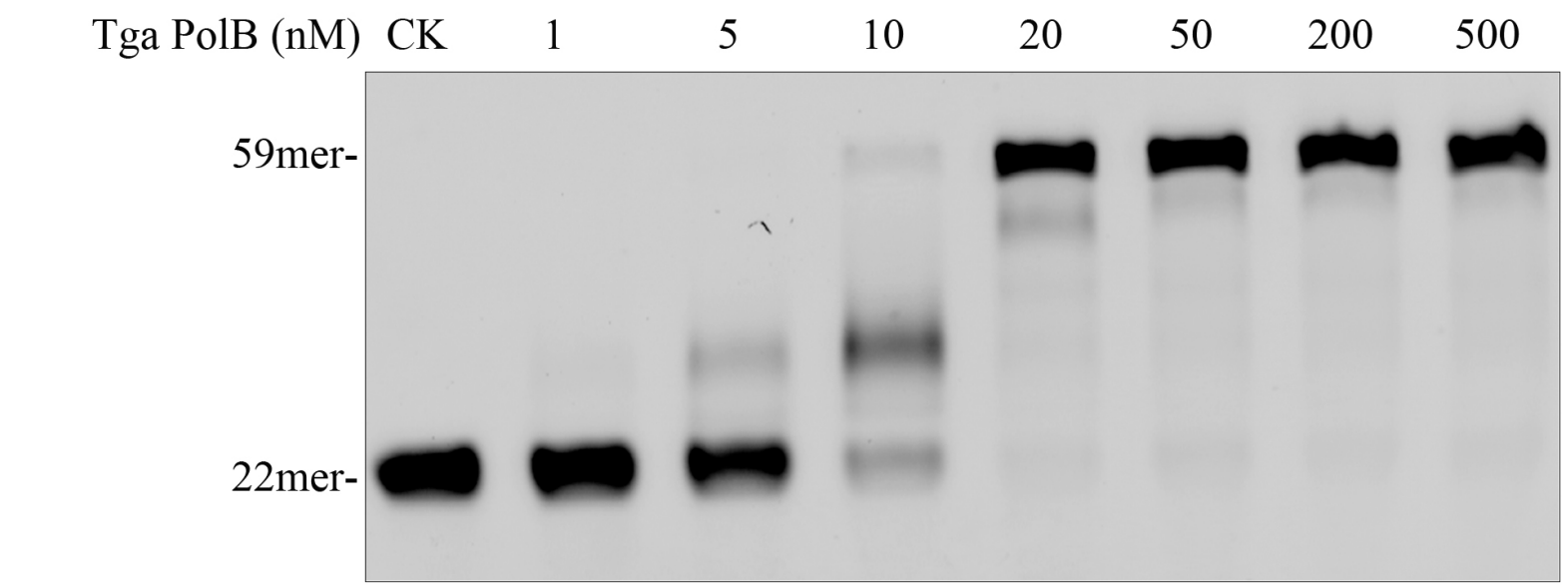

Polymerization (\%)

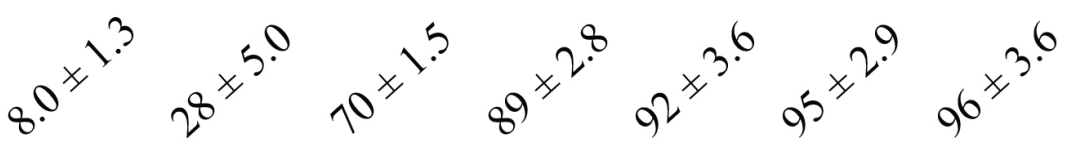




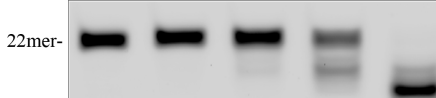

Cleavage (\%)
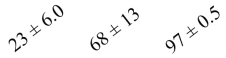

$99^{x^{0.5}}$

$9^{9^{x^{5}}}$

B

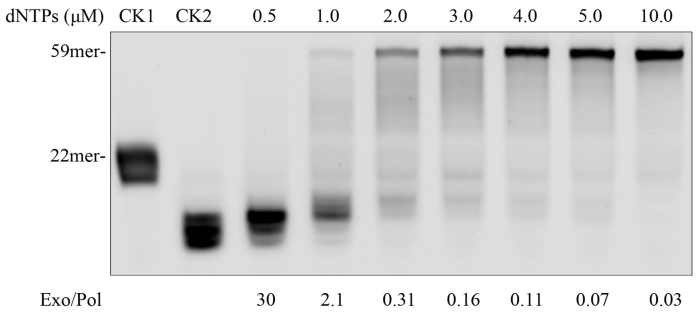




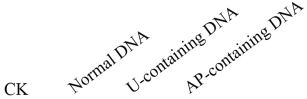

22mer-

59mer-

42mer- 


$\begin{array}{lllllllll}\text { Tga PolB (nM) } & \text { CK } & 100 & 200 & 300 & 400 & 500 & 600 & 700\end{array}$

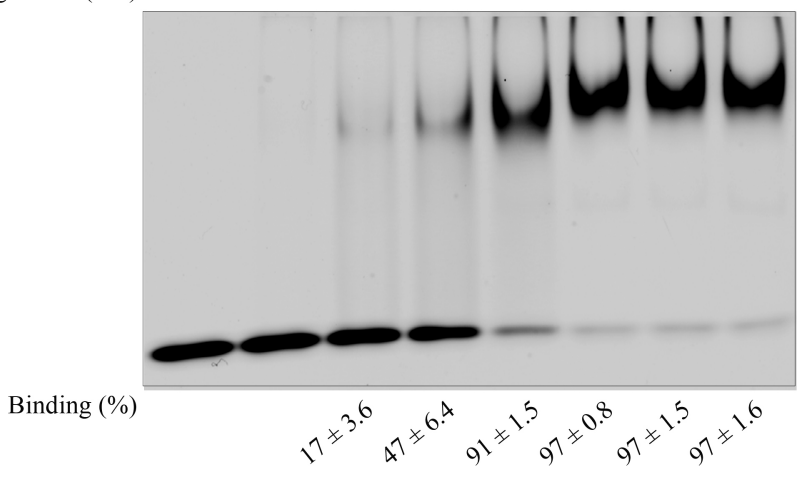

B

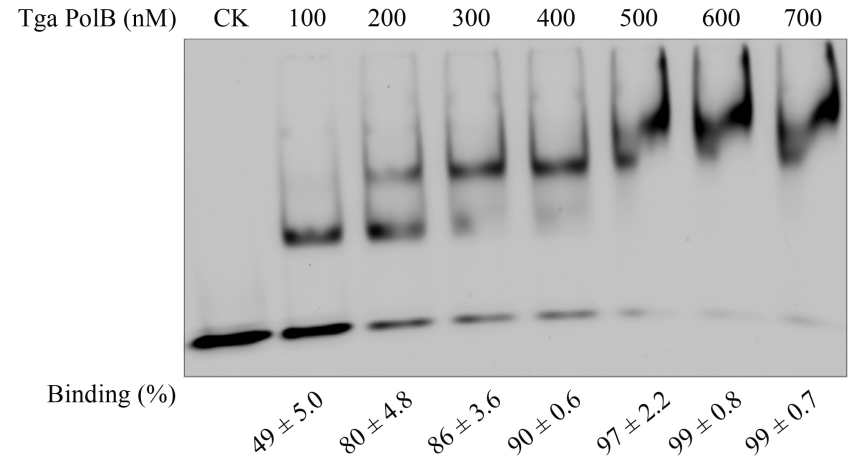

C

$\begin{array}{lllllllll}\text { Tga PolB (nM) } & \text { CK } & 100 & 200 & 300 & 400 & 500 & 600 & 700\end{array}$

Binding (\%)

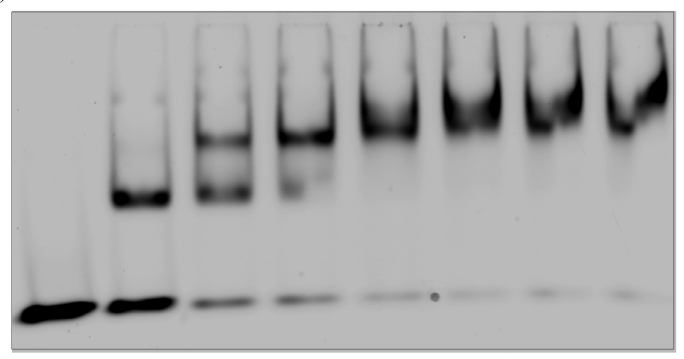

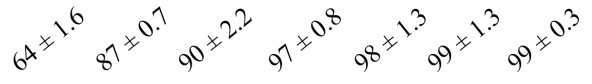




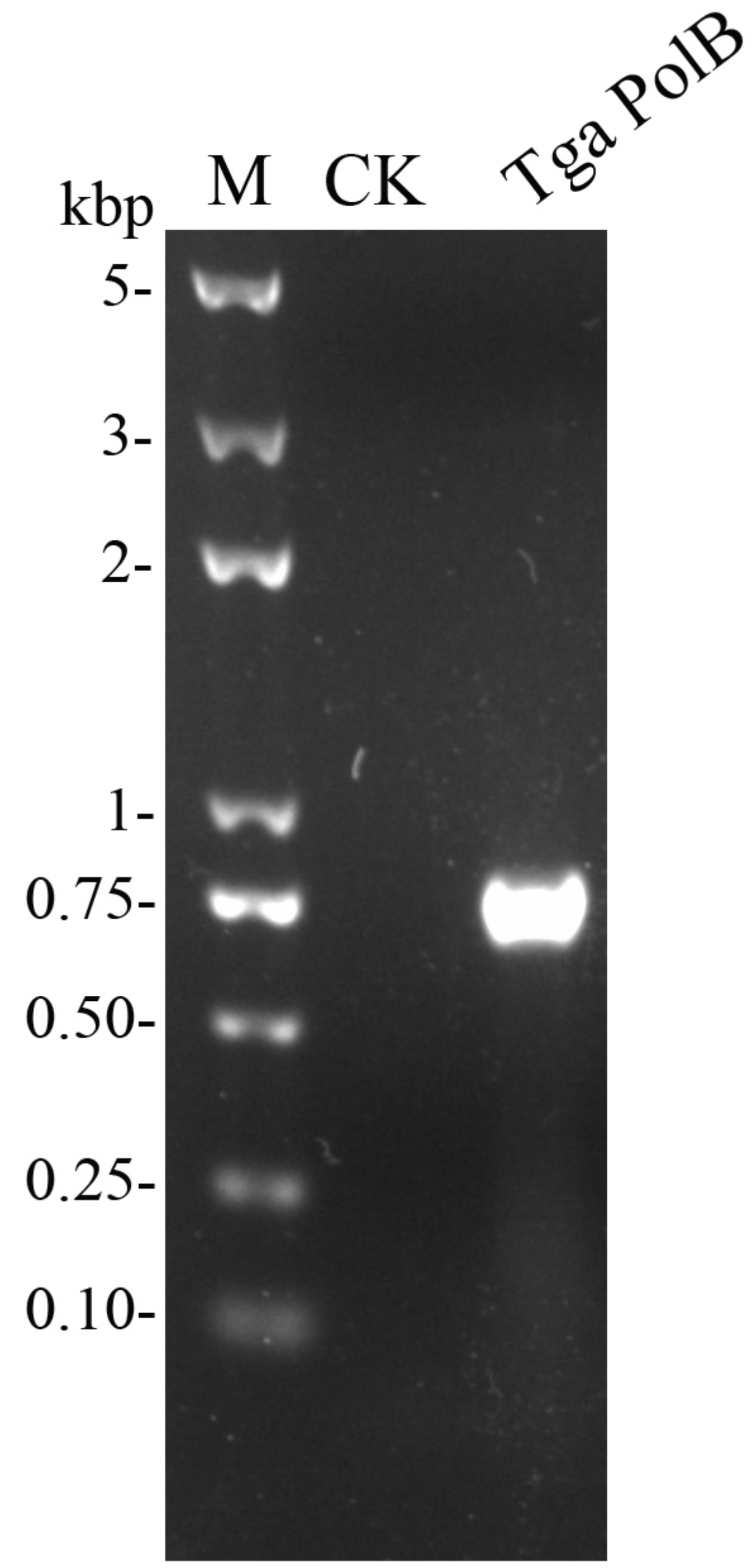




\section{Author Statement}

All authors declare that they have no conflict of interest. This article does not contain any studies with human participants or animals performed by any of the authors. 


\section{SupplementalData}

\section{Characterization and application of a Family B DNA polymerase from the}

hyperthermophilic and radioresistant euryarchaeon Thermococcus

gammatolerans

Likui Zhang ${ }^{1,4 \#, ~ D o n g h a o ~ J i a n g ~}{ }^{1}$, Haoqiang Shi ${ }^{1}$, Mai Wu${ }^{1}$, Qi Gan ${ }^{1}$, Zhihui Yang ${ }^{2 \#, ~}$ and Philippe Oger ${ }^{3 \#}$

${ }^{1}$ Marine Science \& Technology Institute, College of Environmental Science and Engineering, Yangzhou University, Jiangsu Province 225127, China

${ }^{2}$ College of Plant Protection, Agricultural University of Hebei, Baoding City, Hebei

Province 071001, China

${ }^{3}$ Univ Lyon, INSA de Lyon, CNRS UMR 5240, Villeurbanne, France

${ }^{4}$ Guangling College, Yangzhou University

${ }^{\#}$ Corresponding author: Dr. Likui Zhang

Tel: +86-514-89795882

Fax: $+86-514-87357891$

E-mail address: 1kzhang@yzu.edu.cn

Corresponding author: Prof. Zhihui Yang

E-mail address: bdyzh@hebau.edu.cn

Corresponding author: Prof. Philippe Oger

E-mail address: philippe.oger@insa-lyon.fr 


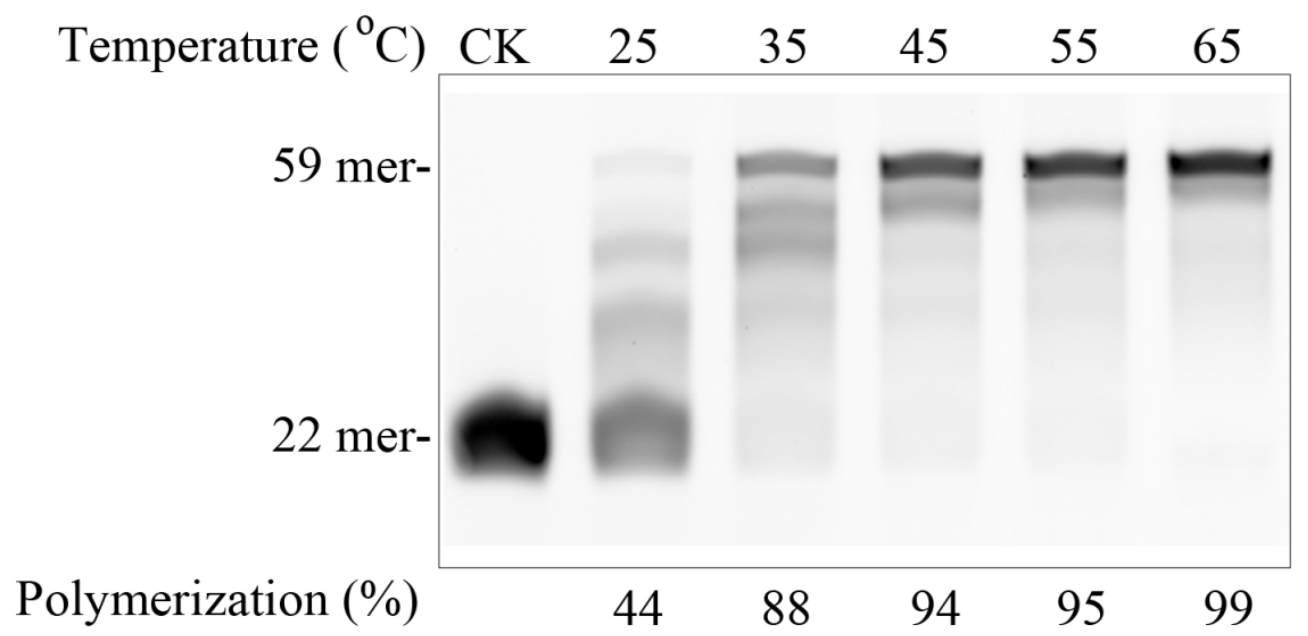

Fig. s1. DNA synthesis of Tga PolB atdifferent temperatures. The DNA synthesis reactions were performed by $50 \mathrm{nM}$ Tga PolB at different temperatures. The synthesizedDNA products were analyzed by running a denaturing polyacrylamide gel. CK: the reaction without the enzyme. 